\title{
LEXICON
}

\section{PROSODIC MORPHOLOGICAL ANALYSIS ON BLENDS USED AS BRAND OF SNACKS AND BEVERAGES}

\author{
Ratna Setyowati
}

\begin{abstract}
This research focuses on the blends used in the brands of snacks and beverages which are found in supermarkets around Yogyakarta. More specifically, it attempts to identify and classify blend into four structural formations using prosodic morphology approach. The syllabic constituents of each source word and the number of syllables of the blends are also analyzed in this research. The findings of this research show that coining each beginning of two words is the structural formations of blends mostly used in the data collected ( 9 blends). It is followed by coining beginning and ending elements of word ( 7 blends), coining two words that have common sequence sounds ( 6 blends), and ended by coining two words that have multiple sounds ( 3 blends). The structural formations that are mostly relevant to the size of blends based on the number of syllables of the second source wordsis $\mathrm{AD}$ formation $(83.33 \%)$. It shows that the structures of blends without overlapping on the source words are more relevant to the theory of size of the blends than the structures of blends with overlapping.
\end{abstract}

Key words: blends, prosodic morphological approach, structural formations, syllabic constituents, size of blends.

\section{Intisari}

Penelitian ini fokus pada perpaduan kata yang digunakan sebagai merek makanan dan minuman ringan yang ditemukan di beberapa toko besar di Yogyakarta. Secara khusus, penelitian ini bertujuan untuk mengidentifikasi dan mengelompokkan perpaduan kata ke dalam empat formasi stuktural dengan menggunakan pendekatan prosodic morphology. Komponen-komponen suku kata dari masing-masing kata sumber dan banyak suku kata dari perpaduan kata juga menjadi bahan yang dianalisis dalam penelitian ini. Hasil penelitian ini menunjukkan bahwa perpaduan antara masing-masing bagian depan kata a dalah formasi struktural dari perpaduan kata yang sering digunakan pada data yang ditemukan (9 perpaduan kata). Struktur ini kemudian dilanjutkan oleh perpaduan antara bagian awal dan akhir dari kata sumber (7 perpaduan kata), perpaduan dua kata yang mempunyai rangkaian bunyi bersama (6 perpaduan kata), dan diakhiri oleh perpaduan dua kata yang mempunyaibunyiberlipatganda (3 perpaduan kata). Formasi struktural yang paling relevan dengan ukuran perpaduan kata yang berdasarkan pada banyaknya jumlah suku kata pada kata sumber kedua adalah formasi AD (83.33\%). Hal ini menunjukkan bahwa struktur dari perpaduan kata tanpa adanya tumpang tindih pada kata sumber lebih relevan terhadap ukuran perpaduan kata daripada struktur perpaduan kata yang bertumpang tindih.

Kata kunci: perpaduan kata, pendekatan prosodic morphology, formasi stuktural, komponen-komponen suku kata, ukuran perpaduan kata. 


\section{INTRODUCTION}

Selling a product means dealing with the customer's desires. To attract the customers, company managers must be able to create appropriate strategies to market the product. One way to achieve the goal is by creating an interesting and easy to remember brand. In this case, using blends turns out to be a good strategy to name a product, and so, to attract the customers. This is supported by Gunelius (2011), who says using blends is one of the ten ways for naming a product to be a good brand. The other ways are be descriptive, use real words with a twist, add a prefix or suffix, create a compound word, make up a word, change spellings, use a place or person's name, create acronym or use initial or numbers, and use a verb ("How to name a Product"). Moreover, making a brand is important because it is always associated with the goal of the brand maker. Hence, blends can make very effective brands (Placek "A History on Blends in Brands").

Bauer's definition of blends is stated to be "a new lexeme formed from parts of two (or possibly more) other words in such a way that there is no transparent analysis into morphs" (234). The term no transparent analysis basically means, two lexemes or more which have been blended into one so that it cannot be separated into morphs anymore. For example, the word brunch, one of the well-known blends, resulted from combining the source words breakfast and lunch. In this case, the word brunch is not composed of the morphemes 'br-' and '-unch'. Instead, it is becoming a monomorphemic lexeme. However, Bauer points out that "in many cases some kind of analysis can be made because at least one of the elements is transparently recoverable" (235).

There are a lot of products that use blends as their brands. Because of that, based on the explanation presented above, it is justifiable to use brands as the data sourceof the research on blends. This research is especially focused on investigating the blends used as brands of snacks and beverages. The brand of snacks and beverages are chosen as the data source because those products can be found easily and available in some supermarkets. Indeed, based on the limitation of the data collection, those selected products are found in local area of Yogyakarta. Some examples of the blends used as brands are given below:
a. chitato
$\rightarrow$ from the combination of the words chips and potato
b. indomilk $\rightarrow$ combination of the words Indonesia and milk
c. richoco $\rightarrow$ combination of the words rich and chocolate

Even though the blends found on the products labels functioned as brands, the process in creating those words seems to be comparable with the process of creating the blends which are not used as brands. According to Bauer (1983) and Plag (2002), structure formations of blends normally take the first part of one word and the last part of another (235). Like the word chitato, the beginning of the first source word 'chip' is combined with the ending of the second source word 'potato'. Furthermore, Bauer also states that blends can be categorized into four structural formations. This intrigues the present writer to investigate to which structural formation thosebrands belong and then examine the most frequent structural formation of blend found in those brands. Besides, the writer also investigates the relevancy of size of blend to each structural formation of blend..

\section{METHOD}

This research focuses on the 25 blends used in brands of snacks and beverages which were found in several supermarkets in Yogyakarta.The data selected are the blends as used in the brands written in English which were found in the local area. In this case, those data selected include some cases when only one of the source words written in English. The discussion is limited to the identification and classification of the blends using prosodic morphological approach. Because of the prosodic morphology deals with the phonology, the data collected are presented based on the prescription of International Phonetic Alphabets (IPA). However, the pronunciation of the data is according to the way the brand maker introduces the product on commercial breaks. Indeed, the pronunciation tends to use Indonesian pronunciation. The data collection technique that the writer used is of two steps. First is taking pictures of the packages of the snacks and beverages available in supermarkets 
around Yogyakarta. Second is identifying the blends out of the brands of those products by guessing the source words of the blend. The results were 25 blends as used in thebrands of snacks and beverages that can be used as the data.

After the data were collected, the writer firstly analyzed the structure of the blends according to Plag's methodology. The data collected are investigated the syllable structure to explain parts of the source words getting involved into the blends. The structure of a syllable is described as having four constituents. There are onset, nucleus, and coda, with nucleus and coda forming the so called rime. In addition that only the nucleus of a syllable must be obligatory filled while the other constituents are in principle optional. To help the reader to understand the discussion, the analysis is presented in tree diagramsof each source word to show the prosodic constituents of the blends. The result of data analysis will be shown in tables of blend types in four structural formations proposed by Bauer (1983). In addition, the writer also analyzed the number of syllable of the blends in determining the size of blends which is based on the number of syllable of the second source word.

Plag proposes a formula for blending, that is $\mathrm{AB}+$ $\mathrm{CD}=\mathrm{AD}$ with $\mathrm{A}, \mathrm{B}, \mathrm{C}$, and $\mathrm{D}$ referring to respective parts of the source words involved. Through the prosodic constituents along with $\mathrm{A}, \mathrm{B}, \mathrm{C}$, and $\mathrm{D}$, it makes easier to see each part of the source words getting into the blends. A refers to the initial element of the first source word, which usually is the onset and the nucleus as the syllabic constituents. B refers to the final part of the first source word, which is usually consisted of the rime or coda. Then $\mathrm{C}$ and $\mathrm{D}$ as the part of the second source word has the same notion on the part of the syllabic elements of A and B.

\section{FINDINGS}

\section{The blend structures and their classifications}

The data were analyzed on their structure by using the prosodic morphology approach in order to identify the prosodic elements of the source words to be deleted or combined into new lexemes. This section presents the categorization of the 25blends along with the structures shown in the prosodic constituents. The following table shows the structural formation of the blend based on Bauer's (1983) classification.

Table 1 The categorization of the blends into four structural formations

\begin{tabular}{|c|c|c|c|c|}
\hline NO & $\begin{array}{l}\text { Structural } \\
\text { Formations }\end{array}$ & Structure & Types & $\begin{array}{c}\text { Number } \\
\text { of } \\
\text { tokens }\end{array}$ \\
\hline 1. & $\begin{array}{l}\text { Coining } \\
\text { beginning and } \\
\text { ending elements } \\
\text { of words }\end{array}$ & $\begin{array}{l}\text { the beginning of } \\
\text { SW1 + the end } \\
\text { of SW2, including } \\
\text { cases when SW1 is } \\
\text { fully preserved }\end{array}$ & AD & $7(28 \%)$ \\
\hline 2. & $\begin{array}{l}\text { Coining each } \\
\text { beginning of } \\
\text { two words }\end{array}$ & $\begin{array}{l}\text { the beginning } \\
\text { of SW1 + the } \\
\text { beginning of } \\
\text { SW2, including } \\
\text { cases when SW1 is } \\
\text { fully preserved }\end{array}$ & $\mathrm{AC}$ & $9(36 \%)$ \\
\hline 3. & $\begin{array}{l}\text { Coining two } \\
\text { words that have } \\
\text { a common } \\
\text { sequence } \\
\text { sounds }\end{array}$ & $\begin{array}{l}\text { the beginning of } \\
\text { SW1 }+ \text { all of SW2 }\end{array}$ & AW & $6(24 \%)$ \\
\hline 4. & $\begin{array}{l}\text { Coining two } \\
\text { words that have } \\
\text { multiple sound }\end{array}$ & $\begin{array}{l}\text { SW1 + SW2, } \\
\text { overlap }\end{array}$ & WW & $3(12 \%)$ \\
\hline
\end{tabular}

Table 1 shows that the coining each beginning of two words is the most dominant structural formation with number of tokens are 9 or $36 \%$. It is then followed by coining beginning and ending elements of words with 7 blends or $28 \%$, coining two words that have common sequence sounds with 6 blends or $24 \%$, and ended by coining two words that have multiple sounds with 3 blends or $12 \%$. It seems the brand makers prefer to combine each initial of source words in making brands. The further discussion of some examples of the blends will be presented below. The examples are numbered in accordance with the list of number presented in the appendices.

\subsection{Coining each beginning of two words}

There are 9 blends of the data that belong to this structural formation. As what has been explained in Chapter II, coining each beginning of two words is a combination of the beginning of the first source word and the beginning part of the second source word, including the cases that the first source word is fully preserved. In the diagrams, A, B, C and D refer to the respective parts of the elements taking parts in the 
blends. $\mathrm{AB}$ refers to the parts of the elements of the first source word and then CD refers to the parts of the elements of the second source word. One of the examples is given below.

(1) Cerevita

a)

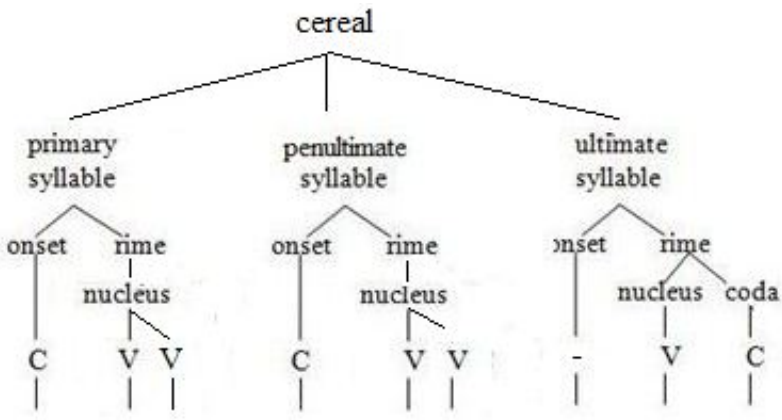

s

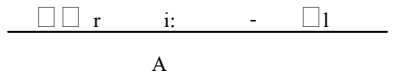

B

b)

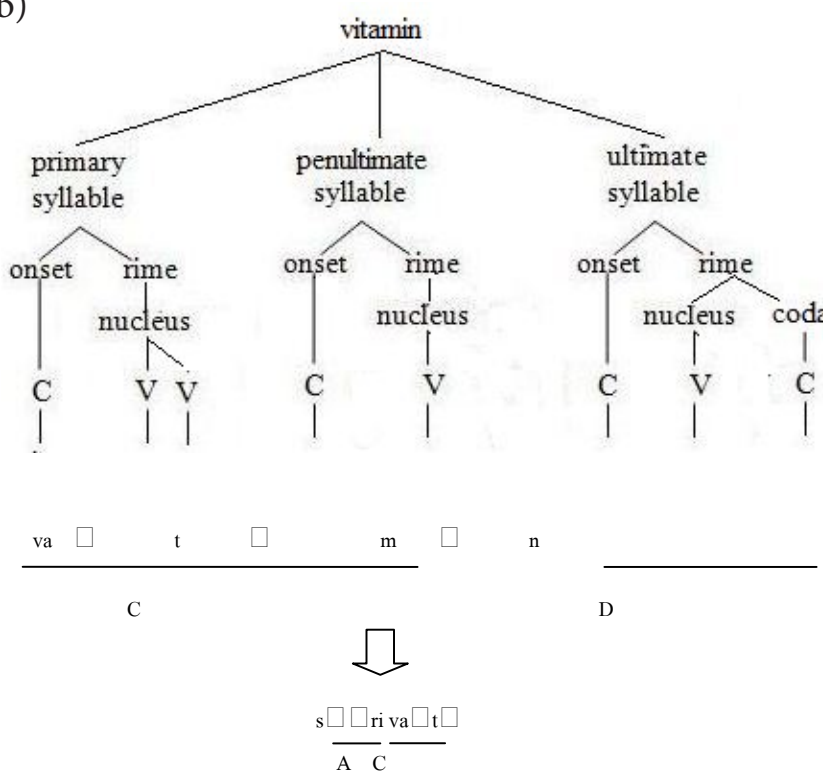

In (1) there are two lexemes which have been blended into one new word cerevita. The blend used in brandcerevita is combined from the word cereal and vitamin. The diagrams above show that A represents the primary and penultimate syllables of the word cereal while B represents the last syllable. Then C represents the first and second syllables of the word vitamin, while $\mathrm{D}$ represents the ultimate syllable of the word vitamin. To form a new lexeme cerevita, $\mathrm{B}$ and $\mathrm{D}$ are deleted. The structure of the blend cerevita is AC and the formula for this type is $\mathrm{AB}+\mathrm{CD}=\mathrm{AC}$. Then, here is no overlapping on the first source word and the second source word. In addition, because of the influence of the Indonesian's accent, the pronunciation changes into /serev $\square \mathrm{t} \square /$.

\subsection{Coining beginning and ending elements of words}

Coining beginning and ending element of words is combined from the initial part of the first source word and the last part of the second source word, including cases when the first source word is fully preserved, so it can be formulated as $\mathrm{AD}$ structure. From the table above there are 7 blends that are classified into this type. Below is the example:

\section{(2) Chitato}

a)

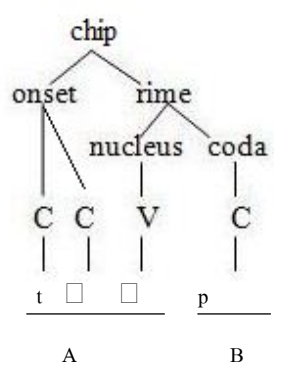

b)
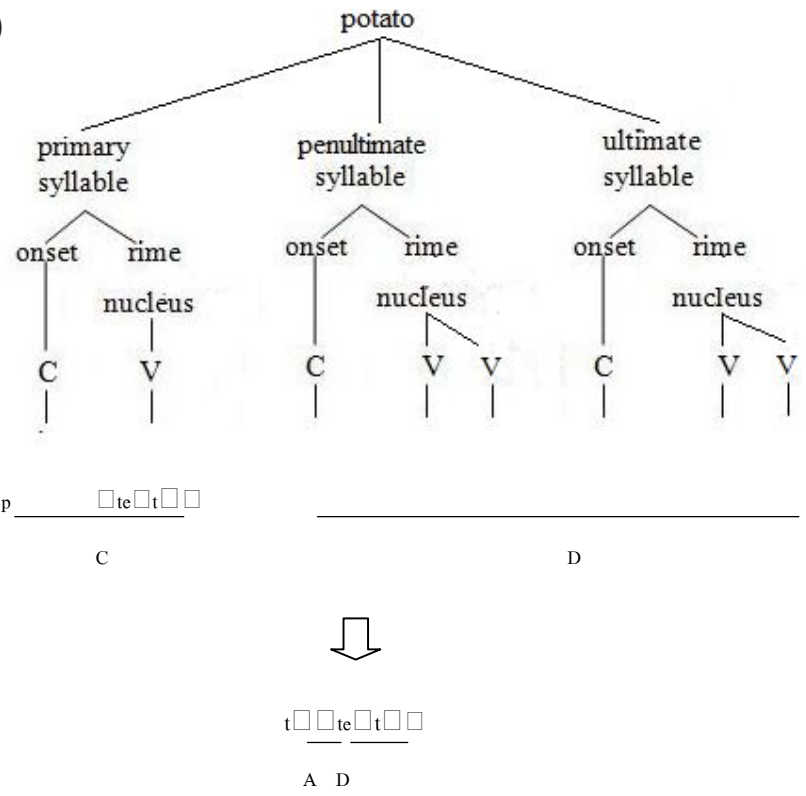

The blend chitato obviously deals with the existing two words that are shortened to form a new word. The meaning of that blend is one where the second source word modifies the first source word. Thus, a chitato is a kind of chip (potato as part of the chip). From the 
information given in the packaging of the product label, chitato means a chip which is made from potato.

Apart from the meaning of the blend chitato, its structure is the beginning of the first source word chip and the end of the second source word potato. As seen in the diagrams that $B$ and $C$ are unacceptable into the blend structures. B refers to the coda of the first source word while $\mathrm{C}$ refers to the first syllable of the second source word, and so B and $\mathrm{C}$ are deleted in composing the blend chitato. Therefore, the word potato does not overlap with the first source word. However, the pronunciation of the word chitato changes into/ $\mathrm{t} \square \square \mathrm{t} \square \mathrm{t} \square \square$ /based on Indonesian pronunciation. Moreover, the structure of the blend chitato is accepted according to the blending rule proposed by Plag, $\mathrm{AB}+$ $\mathrm{AC}=\mathrm{AD}$. A refers to the onset and nucleus of the first source word while D refers to the penultimate and the ultimate syllables of the second source word.

\subsection{Coining two words that have common sequence sounds}

Coining two words that have common sequence sounds can be described as the blend types which has AW formation as the structural formations of the blends. AW formation means that A is the initial part of the first source word while $\mathrm{W}$ is the complete syllables of the second source word. Although the second source word is entirely present in the blend, it does not mean that there is an overlapping. There are 6 blends belong to this type. The example of the word for this type is given below.

\section{(3) Comberry}
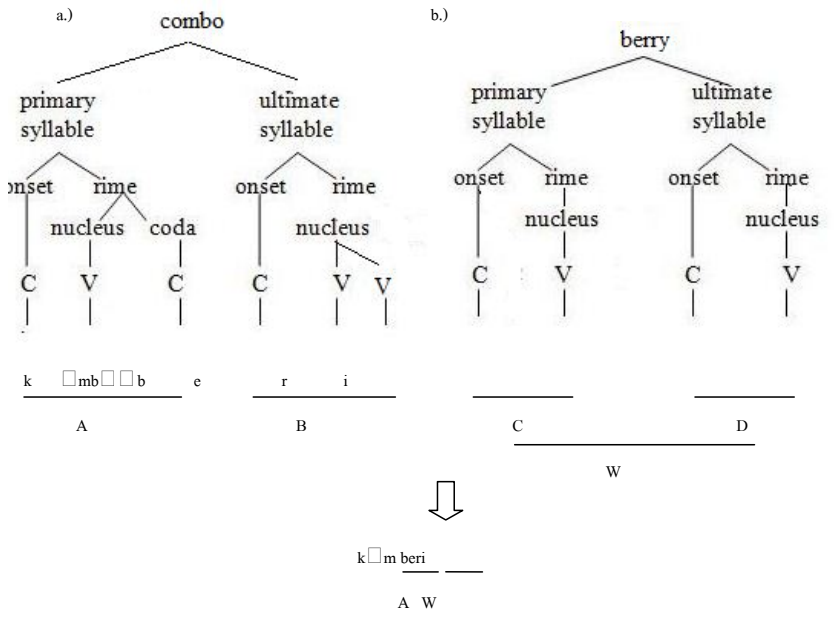

As seen in the diagrams, A represents the primary syllable of the word combo while B represents the ultimate syllable. Because the second source word berry takes part in full parts into the blends, C and $\mathrm{D}$ do not transparently represent each part of the elements. In this case, CD transforms into $\mathrm{W}$ which is more representative to cover the complete syllables of the second source word. Comberry is a combination of the words combo and berry. The onset of the ultimate syllables of the word combo overlaps with the onset of the primary syllables of the word berry. It can be concluded that only the nucleus of the ultimate syllable of the first source word is deleted. As the result, the structure of the blend comberry is AW.

\subsection{Coining two words that have multiple sounds}

The last type of the structural formation of the blends is coining two words that have multiple sounds. It means that there is overlapping on the first source word and the second source word. There are 3 blends used in the brands that belong to this type. They are:

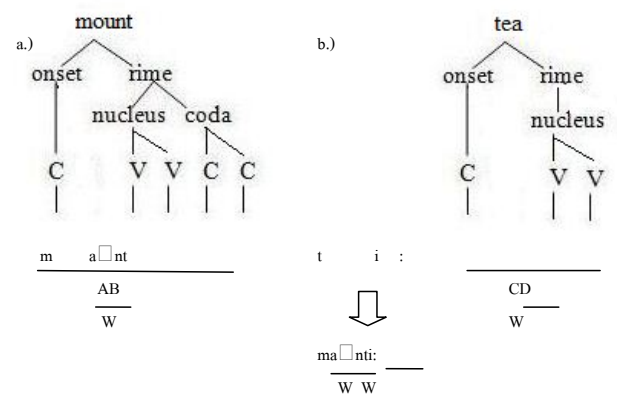

(4) Mountea

As can be seen from the diagrams, the blend mountea is constructed from both of the monosyllabic words mount and tea. In order to describe the complete elements of the source word more obvious, $\mathrm{AB}$ as the part of the first source word and CD as the part of the second source word are transformed into $\mathrm{W}$. The overlapping is on the sound / $t$ / as the coda of the word mount and the onset of the word tea. Because of that, both of the source word are transparently noticeable. It can be demonstrated like this: mount + tea $\rightarrow$ mountea (the overlapping part is on the bold type). The structural formation is WW, with W referring to the complete syllables of the source words. 
(5) Richeese
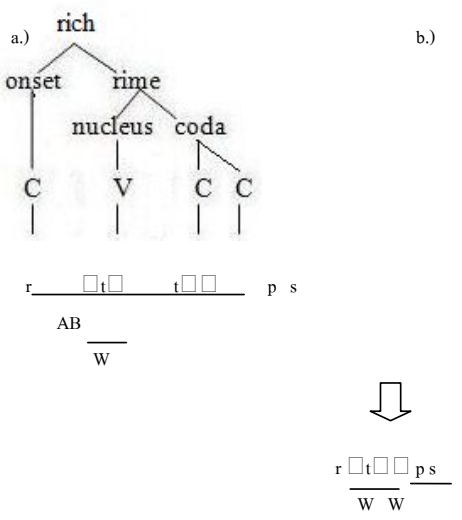

(6) Richips

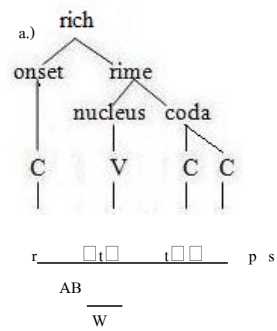

乙

$\frac{\mathrm{r} \square \mathrm{t} \square \square \mathrm{ps}}{\mathrm{W} \mathrm{W}}$

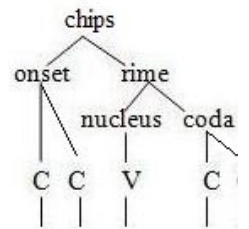

$\mathrm{CD}$

W

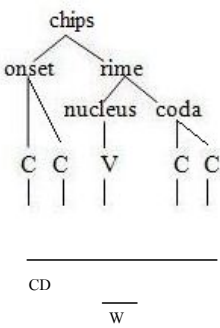

source word and the final part of the second source word. It is also noted that the first source word can be preserved in complete syllables. Thirdly, the initial part of the first source word is combined with the complete syllables of the second source word, with AW as the formation of the blends. The last structure is that there is an overlapping on the final part of the first source word and the initial part of the second source word and so that both of the source words are entirely present in the blend, or can be token as WW type.

\section{The number of syllables of the blends}

This section discusses the number of syllables of each source word of the blends to see the correlation between the number of syllables of the source words and the size of the blends. As stated before that the size of blends can possibly be determined bythe number of syllables of the second source word. The following chart shows the number of syllables of the blends based on the number of syllables of the source words.

\section{Chart 1 The number of syllables the blends based on the number of syllables of the source words.}

As seen on the diagrams (5) and (6), the blends richeese and richips are similar to the previous example on the diagrams (4). Those blends are constructed from both of the monosyllabic words. The source words rich and cheese overlap in resulting the blend richeese: rich + cheese $\rightarrow$ richeese. The overlapping of the blend richeese is on the sound $/ t \square /$ as the coda of the first source word and the onset of the second source word. The overlapping part of the blend richips is similar to the blend richeese, that is rich + chips $\rightarrow$ richips. It can be stated that both of the source words are entirely present in the blends and obviously visible.

Overall, to summarize the discussion, it is found that the structure of blends can be elaborated into four types using prosodic constituents. The data collected are looked deeper only on the syllabic constituents (onsets, nuclei, codas, rimes, or complete syllables). The first structure is that the initial part of the first source word is combined with the initial part of the second source word, which is then called AC formation. This type includes the cases that the first source word is entirely present in the blend. Secondly, AD formation is accepted according to the blending rule $(\mathrm{AB}+\mathrm{CD}=$ $\mathrm{AD}) . \mathrm{AD}$ is a combination of the initial part of the first

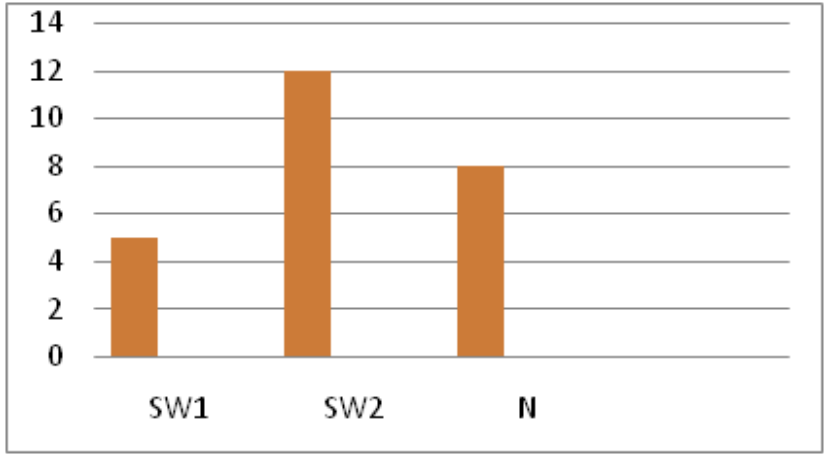

Notes: SW $1 \rightarrow$ the first source word; SW2 $\rightarrow$ the second source word; $\mathrm{N} \rightarrow$ neither SW1 nor SW2

The chart above shows the similarity degree of the syllable number of the source words on the number of syllables of the blends formed. It can be confirmed that the number of syllables of the second source word is the highest numberthat has the same number of syllables of the blends. There are 12 blends or $48 \%$ which number of syllables of the second source word are the same with syllable number of the blends Then there are 8 blends or 32\% which neither the number of syllables of the first source word nor the number of 
syllables of the second source word are similar to the syllable number of the blends. It is then followed by 5 blends or $20 \%$ which number of syllables of the first source word are similar with the number of syllables of the blends. In order to see the structural formation which is the most relevant to size of blends, the syllable number of the source words and syllable number of the blendsof each formation are presented below.

Table 2 The number of syllables of the blends belonged to $\mathrm{AC}$ formation

\begin{tabular}{|c|l|l|l|c|c|c|}
\hline \multirow{2}{*}{ NO } & \multicolumn{2}{|c|}{ Source words } & \multirow{2}{*}{ Blends } & \multicolumn{3}{c|}{$\begin{array}{c}\text { The number of } \\
\text { syllables }\end{array}$} \\
\cline { 2 - 7 } & AB & CD & AC & AB & CD & AC \\
\hline 1 & fresh & coffee & fresco & 1 & 2 & 2 \\
\hline 2 & cereal & vitamin & cerevita & 3 & 3 & 4 \\
\hline 3 & happy & cokelat & happy-co & 2 & 3 & 3 \\
\hline 4 & happy & vanilla & happy-va & 2 & 3 & 3 \\
\hline 5 & hydro & coconut & hydrococo & 2 & 3 & 4 \\
\hline 6 & hot & sambal & hotsa & 1 & 2 & 2 \\
\hline 7 & nutrition & jelly & nutrijell & 3 & 2 & 3 \\
\hline 8 & rich & chocolate & richoco & 1 & 3 & 3 \\
\hline 9 & super & cokelat & superco & 2 & 3 & 3 \\
\hline
\end{tabular}

Note: the highlight shows the same number of syllables

From the table above, there are 6 blends from the total blends of $\mathrm{AC}$ formation which number of syllables of the second source word is similar to the syllable number of the blends. Then only one blend has the same number of syllables with number of syllables of the first source word, and two blends which number of syllables of the source words is different from syllable number of the blends. It shows that $66.67 \%$ of AC formation is relevant to the theory of the size of blends.

Table 3 The number of syllables of the blends belonged to $\mathrm{AD}$ formation

\begin{tabular}{|c|l|l|l|c|c|c|}
\hline \multirow{2}{*}{ NO } & \multicolumn{2}{|c|}{ Source words } & \multirow{2}{*}{ Blends } & \multicolumn{3}{c|}{$\begin{array}{c}\text { The number of } \\
\text { syllables }\end{array}$} \\
\cline { 2 - 7 } & \multicolumn{1}{|c|}{ AB } & \multicolumn{1}{|c|}{ CD } & \multicolumn{1}{|c|}{ AD } & AB & CD & AD \\
\hline 1 & chip & potato & chitato & 1 & 3 & 3 \\
\hline 2 & ice & espresso & icepresso & 1 & 3 & 3 \\
\hline 3 & fruit & vitamin & frutamin & 1 & 3 & 3 \\
\hline 4 & happy & potatos & happy-tos & 2 & 3 & 3 \\
\hline 5 & soy & delicious & soylicious & 1 & 3 & 3 \\
\hline 6 & indonesia & nata de coco & inaco & 4 & 5 & 3 \\
\hline 7 & next & nastar & nextar & 1 & 2 & 2 \\
\hline
\end{tabular}

As seen from the table above, there are 6 blends from the total blends of $\mathrm{AD}$ formation whose number of syllables of the second source word is similar to the number of syllables of the blends. The other blend has the different number of syllables of source words from number of syllables of the blends. It can be estimated that about $83.33 \%$ of $\mathrm{AD}$ formation is relevant to the size of blends.

Table 4 The number of syllables of the blends belonged to AW formation

\begin{tabular}{|c|l|l|l|c|c|c|}
\hline \multirow{2}{*}{ NO } & \multicolumn{2}{|c|}{ Source words } & \multirow{2}{*}{ Blends } & \multicolumn{3}{c|}{ The number of } \\
& \multicolumn{2}{|c|}{ syllables } \\
\cline { 2 - 7 } & SW1 & SW2 & SW1+SW2 & SW1 & SW2 & Blends \\
\hline 1 & cokelat & cone & cocone & 3 & 1 & 2 \\
\hline 2 & combo & berry & comberry & 2 & 2 & 3 \\
\hline 3 & indonesia & café & indocafe & 4 & 2 & 4 \\
\hline 4 & cereal & mix & ceremix & 3 & 1 & 3 \\
\hline 5 & indonesia & milk & indomilk & 4 & 1 & 3 \\
\hline 6 & nutrition & boost & nutriboost & 3 & 1 & 3 \\
\hline
\end{tabular}

None of the blends from the total blends of AW formation whose number of syllables of the second source word is similar with syllable number of the blends. However, there are 3 blends whose number of syllables of the blends is similar to number of syllables of the first source word, and 3 other blends which number of syllables of each source word is different from number of syllables of the blends. Therefore, AW formation is irrelevantto the size of blends.

Table 5 The number of syllables of the blends belonged to $\mathrm{WW}$ formation

\begin{tabular}{|c|l|c|l|c|c|c|}
\hline \multirow{2}{*}{ NO } & \multicolumn{2}{|c|}{ Source words } & \multirow{2}{*}{ Blends } & \multicolumn{3}{|c|}{$\begin{array}{c}\text { The number of } \\
\text { syllables }\end{array}$} \\
\cline { 2 - 7 } & SW1 & SW2 & SW1+SW2 & SW1 & SW2 & Blends \\
\hline 1 & mount & tea & mountea & 1 & 1 & 2 \\
\hline 2 & rich & cheese & richeese & 1 & 1 & 2 \\
\hline 3 & rich & chips & richips & 1 & 1 & 2 \\
\hline
\end{tabular}

Similar to the AW formation, none of the blends from the total blends of WW formation whose number of syllables of the second source word is similar with syllable number of the blends. Indeed, all of the number of syllables of the data collected is different from number of syllables of the blends. As a result, WW formation is irrelevant to of the size of blends.

From the discussion, it can be summarized that the number of syllables of the blends can be determined 
by the number of syllables of the second source word. The highest accuracy of the size of blends is the AD formation or coining the beginning and ending of the words with $83.33 \%$. It is then followed by the AC formation with $66.67 \%$. This shows that the structures of the blends without overlapping on the source words ( $\mathrm{AD}$ and $\mathrm{AC}$ ) are more relevant to the size of the blends than to the structures of blends with overlapping (AW and WW).

\section{CONCLUSION}

The research shows that the data identified are 25 blends used in the brands of snacks and beverages which are found in supermarkets around Yogyakarta. Based on the data analysis and the result of the research in the previous chapter, the structural formations used mostly in the data collected are the coining each beginning of two words (AC formation). AC formation and $\mathrm{AD}$ formation as the higher number than the other structures of blends. It seems to suggest that the brand makers prefer making shortened blend of the source words than combining complete syllables. Besides, in the discussion of number of syllables of the blends, it proves that number of syllables of the second source word fulfill the size of blends proposed by Plag (2002). The structural formation that is mostly relevant to the size of blends is $\mathrm{AD}$ formation with $83.33 \%$ of accuracy.

Prosodic morphology approach has proven to be a very important aspect in investigating the structural formations of blends. Without it, the part of the source words which get into the blends cannot be determined clearly. By applying the prosodic constituents along with the part of the source words which are denoted as $\mathrm{A}, \mathrm{B}, \mathrm{C}$, and $\mathrm{D}$, the involving parts of the source words in the blends can be identified easier. Prosodic constituents also help to see if there is an overlapping on the end of the first source words and the beginning of the second source words or not.

Generally, the result of this study is evidently different from the previous studies in literature review. In this research, $\mathrm{AC}$ formation is found mostly based on the data collected. This finding is different from Eva's (2010) who found that AW formation is found mostly based on her data collected. The result of Gries's (2004) is totally different from this present research. The finding of Gries is that blends exhibit many structural characteristics. Their structure is governed by a desire to guarantee the recognizability of both source words. On the other hand, Beliaeva's (2014) goal is to distinguish between blends and the 'neighbouring' word formation categories, primarily clipping compounds. Beliaeva finds that the difference between those formations is in the degree of shortening of the original constituents from no shortening at all in compounds to substantial shortening in clipping compounds.

This study uses the brands of snacks and beverages as the data sources which were found in local area of Yogyakarta. Another factor that makes the result of the research different is the different approach between the previous studies and the present studies. This study applies the prosodic morphological approach in investigating the structural formations of the blends. In particular, there are two points which are investigated in this research. The first is the syllabic constituents and the second is the size of blends. Therefore, this study is expected that it can be used as a sample study on blends with the brands as data source.

\section{REFERENCES}

Adams, Valerie. Complex words in English. Harlow: Longman, 2001. Print.

Bauer, Laurie. English word-formation. Cambridge: Cambridge University Press. 1983. Print

Beliaeva, Natalia. "Unpacking Contemporary English Blends: Morphological Structure, Meaning, Processing" (2014). Web. 16 Oct. 2014. <http:// researcharchive.vuw.ac.nz/xmlui/bitstream/ handle/10063/3619/ thesis.pdf $>$.

Gries, Stefan T. "Some Characteristics of English Morphological Blends." Papers from the Regional Meeting. 38 (2002): 201. Print.

----. "Shouldn't it be breakfunch? A quantitative analysis of blend structure in English."Linguistics (2004). Web. 14 May 2014. <http://www.linguistics.ucsb. edu/faculty/stgries/research/2004_STG_Blends_ Linguistics.pdf>

Gunelius, Susan. "How to Name a Product". 10 Tips for Product Naming Success. (2011). Web. 10 Jan. 2015. <https://aytm.com/blog/research-junction/ how-to-name-a-product-10-tips-for-productnaming-success/> 
Hargraves, Orin. New Word. New York: Oxford University Press. 2004. Print.

Hornby, A.S. Oxford Advanced Learner's Dictionary. Oxford: Oxford University Press. 2005. Print.

Lehrer, A. "Identifying and Interpreting Blends: an Experimental Approach." Cognitive Linguistics. 7.4 (1996): 359-390. Print.

----. "Blendalicious." Lexical creativity, texts and contexts: The morphology/stylistic interface. Ed. J. Munad. Amsterdam \& Philadelphia: Benjamins. 2007. Print.

Nurfatimah, Eva. English Word Blends (2010).Web. 9 Jun.2014. <https://abudira.files.wordpress. com/2012/06/word-blending-ada-berapa.pdf>
Pound, Louise. Blends: Their relation to English word formation. Amsterdam: Swets \& Zeitlinger. 1967. Print.

Placek, David. "A History of Blends in Brands, from Early Hominids to Exencial." Lexicon Blog. (2012). Web. 4 Jun.2014. <http://blog.lexiconbranding. com/2012/06/04/a-history-of-blends-in-brandsfrom-early-hominids-to-exencial/>

Plag, Ingo.Word-formation in English. Cambridge: Cambridge University Press. 2002. PDF file.

Russell, Tony, Allen Brize, and Elizabeth Angeli. "MLA Formatting and Style Guide." The Purdue OWL. Purdue U Writing Lab, 4 Apr. 2010. Web. 19 Dec.2014.<http://owl.english.purdue.edu/owl/ resource/747/01/> 